http://dx.doi.org/10.5007/1980-3532.2012n8p148

\title{
Sobre a Integração e Cidadania Europeias
}

\author{
Rogerio Duarte Fernandes dos Passos \\ Doutorando em Educação pela Universidade Estadual de Campinas (UNICAMP) \\ Professor do Centro Estadual de Educação Tecnológica Paula Souza (CEETEPS-SP) \\ rdfdospassos@hotmail.com
}

SCHMIDT, Rainer; RICHTER, Thomas (orgs.). Integração e Cidadania Europeia. São Paulo: Saraiva, 2011, 616 p.

Originais recebidos em: 28/03/2013

Aceito para publicação em: 09/05/2013

Em um momento em que se discute com intensidade se os Estados nacionais ainda são unidades centralizadoras de poder diante dos fenômenos da globalização e mundialização, surge a obra Integração e Cidadania Europeia, organizada por Thomas Richter, professor visitante na Faculdade de Direito da Universidade de São Paulo (USP), e Rainer Schimdt, professor visitante na Faculdade de Filosofia, Letras e Ciências Humanas da USP e ocupante da Cátedra Martius da mesma instituição, sendo que ambos contam com o apoio do Serviço Alemão de Intercâmbio Acadêmico (Deutscher Akademischer Austauschdienst - DAAD).

Introduzida pelo Tratado de Maastricht de 1992, a cidadania europeia representa significativa novidade no tema na medida em que tenta não ter o Estado nacional como única base e tenta nele não se exclusivamente apoiar para a sua configuração. Diante disso, intenciona-se estruturar uma cidadania cujo alicerce não se dá apenas em uma unidade política tradicional - o Estado - mas sim em uma unidade de caráter difuso, cuja configuração mais próxima toma o formato de uma organização internacional, in casu, a União Europeia. 
Trabalhando diferentes temas - perpassando a ciência política e o próprio direito internacional - a obra tenta desvendar o possível destino final - ou, ao menos, a situação embrionária desse conceito -, que na perspectiva contemporânea, objetiva superar o status de exercício de direitos políticos e da potencial capacidade de interferência nos negócios jurídicos do governo e do Estado. Nesse ínterim, não deixa de ser paradoxal que ao lado de uma cidadania pelo menos em tese possivelmente ampliada - representada no projeto da União Europeia - e sublinhada por um ideário de "cidadania mundial" e de uma "cidadania comum" - tão alardeado através de questões relacionadas ao combate à pobreza e à proteção do meio ambiente -, o exercício e gozo dos direitos econômicos ainda reste como pilar para a sua visualização, corroborando e legitimando uma diferenciação dos seres humanos no plano material da existência.

Lembre-se que um desafio a persistir ao tema, igualmente, é a própria superação da cidadania como um atributo decorrente da nacionalidade - e seus mecanismos tradicionais de aquisição alicerçados no jus solis e jus sanguinis -, indo além dos elos jurídicos e dos sentimentos de pertencimento relacionados ao arcabouço de uma cultura e destino comuns, no que, no projeto da União Europeia em construção, tem-se a tentativa de estruturação de um sistema democrático que permita a participação das diferentes cidadanias nacionais nas eleições municipais, de maneira que nelas possa um indivíduo votar e ser votado. Acresça-se ao escopo dessa construção e aos direitos fundamentais daí decorrentes - inclusive consagrados na Carta dos Direitos Fundamentais da União Europeia elaborada em 1999 - o direito do jurisdicionado de obter uma boa administração do Poder Público, o acesso a documentos e ao sistema judiciário - além do correlato direito de petição -, associados à livre circulação de há muito consagrada através do mercado comum combinada com o não linear direito de permanência e residência, somados ao de proteção consular e diplomática por parte de qualquer Estado da União.

Em particular sobre este último, denotando um alargamento do mecanismo de proteção contido no direito internacional, tem-se, por outro lado, o resquício do Estado nacional enquanto ponto de apoio dessa tentativa de nova cidadania, mesmo porque, como ressaltado pelo próprio arcabouço jurídico da União Europeia, ela é completar a cidadania nacional e não a substitui.

Ressalte-se que parte da obra dedica-se à salutar aproximação dos temas da União Europeia com o Mercado Comum do Sul (MERCOSUL) - bloco econômico que traz na qualidade de membros fundadores Argentina, Brasil, Paraguai e Uruguai -, 
muito embora a distância entre a realidade deste com a europeia seja muito grande, não apenas no desvelar de processos que guardam significativa distância histórica, mas pela própria particularidade cultural dos países do subcontinente americano, que, em princípio - e pelo menos por ora -, não permitem a visualização de uma conformação institucional que supere os ditames de uma união aduaneira imperfeita.

Em guisa de conclusão, Integração e Cidadania Europeia, coordenada por Thomas Richter e Rainer Schmidt traz uma significativa contribuição à compreensão do estágio atual de tentativa de desenvolvimento de uma cidadania europeia e de suas naturais intercorrências nos campos do direito internacional e da ciência política, permitindo, através da comparação com a trajetória histórica da União Europeia - e o mútuo conhecimento daí decorrente -, proporcionar até mesmo melhor entendimento acerca do que temos e do que efetivamente queremos em termos institucionais no MERCOSUL. 